\title{
Comparison of Two Optimization Models in Assessing LQ-45 Index Optimal Portfolio Performance
}

\author{
Putu Ayu Anggya Agustina \\ Maria Mediatrix Ratna Sari \\ Master Program in Accounting, Udayana University, Jl. 80323 PB Sudirman Denpasar, Indonesia
}

\begin{abstract}
Investment in essence is the placement of funds at this time in the hope of gaining profits in the future. It is necessary for investors to divide funds into several types of investments to reduce the risk borne by choosing an analysis model as a basis for decisions to decide. This study uses two model analysis approaches, namely Markowitz Mode and Black Litterman Model. This research was conducted on the LQ-45 Index on the Stock Exchange from February 2015 to Jauari 2018. The sample selection technique used was purposive sampling technique and obtained 36 observations with a total observation of 108 . The analysis technique used was the Wilcoxon Ranks Test. The results of the study show that the Markowitz Model has a better advantage compared to the Black-Litterman Model. This causes no short sales in the Markowitz Model, whereas in the BlackLitterman Model shows the view of investors who are subjective in analyzing portfolio performance, namely the results of analysis that cannot explain with certainty. Therefore, there is a need for consideration for investors to be able to combine the results of the analysis with the conditions that occur at this time.
\end{abstract}

Keywords: Markowitz Model, Black Litterman Model, LQ-45 Index

DOI: $10.7176 /$ RJFA/10-12-05

Publication date:June $30^{\text {th }} 2019$

\section{Introduction}

Investment in essence is the placement of a number of funds at this time in the hope of gaining profits in the future. One form of investment is stock investment in the capital market. Investors are expected to invest all funds owned not only on one asset, because if the asset fails then all invested funds will be lost. Seeing this impact, investors must reduce the risks borne by diversifying investments. Implementation of this method is that investors divide funds into several types of investments to reduce the risks borne (Djamaluddin et al., 2017). This is in accordance with the basic concept of portfolio theory which is the selection of a combination of individual assets or securities by determining the proportion of funds to be placed on each investment instrument (Mary and Rathika, 2015).

The use of analysis in assessing this portfolio needs to be done for good decision making for investors and potential investors. The existence of the LQ-45 Index which is the choice of the 45 best stocks on the Indonesia Stock Exchange (IDX) can help investors make investment decisions. Investors have become more focused in analyzing stock price movements and the fluctuating Composite Stock Price Index (CSPI). Some things that make fluctuations in stock prices and the JCI are the tax amnesty policy and the political sentiment of the United States election that was chosen by Donald Trump as president of the United States. This sentiment created a social upheaval that occurred on November 4, 2016 which caused the JCI to decline (Hangonowati and Faisal, 2017). But on June 8, 2017, the Ministry of Finance of the Republic of Indonesia through the website www.kemenkeu.go.id said that based on the results of the UNCTAD survey in the 2017 World Investment Report related to Investment and the Digital Economy that Indonesia had risen to fourth place as a destination country prospective investment for 2017 to 2019 (Ministry of Finance of the Republic of Indonesia, 2017).

The existence of this issue makes this study interested in examining the LQ-45 Index which can be used as a reference for the stock portfolio. This portfolio formation analysis uses the Markowitz Model and the BlackLitterman Model because the model is said to be a model capable of assessing portfolio performance well (Kshatriya and Prasanna, 2014; Ramadhan et, al., 2014; and Mahmuda and Subekti, 2017). Based on this, the study compares two optimization models in assessing the optimal portfolio performance of the LQ-45 Index.

According to Markowitz (1952) portfolio theory provides the assumption that investors are rational, which means that investors tend to maximize returns by minimizing risk to diversify stocks and form portfolios. This study uses the Sharpe ratio of two optimization models as an assessment of portfolio performance by not imposing restrictions on the Markowitz optimization model, so it is expected that portfolio formation through the Markowitz Model is able to provide a model analysis that is better than the Black-Litterman Model using market capitalization as a weight for the covariance variance matrix .

Martin and Lukas (2015) conducted a study on the Dow Jones Industrial Average Index (DJIA) to build portfolios using the Marowitz Portfolio Theory (MPT) and the Capital Asset Pricing Model (CAPM) used to calculate the weight of individual securities in the portfolio. The portfolio results developed in this study were randomly selected between available stocks compared to the portfolios of all indices which showed relatively 
high stock performance on the United States (US) market. The parameters of the resulting portfolio do not differ too much from other portfolios even though they are randomly selected.

Wirawan (2017) aims to test the performance of stock portfolios based on momentum strategies with the Black-Litterman Model on the IDX with 120 research samples. The results of the study that the Black Litterman Model is able to provide a Sharpe ratio higher than the Markowitz Model because this study assumes that portfolio stock performance does not limit short sales, it will provide good performance.

Kshatriya and Prasanna (2014) want to expand the portfolio of Markowitz's theory (mean-variance) by adding higher moments such as Skewness and Kurtosis in return characteristics. The research sample consisted of 200 shares contained in the Bombay Stock Exchange (BSE). This study concludes that variance is not the only risk that must be considered when building a portfolio that is clearly visible in the recovery phase. However, minimizing the advantages of Kurtosis and maximizing Skewness are ways to improve the performance of portfolio returns.

Ramadhan et, al. (2014) conducted a study to find out, compare, and analyze optimal portfolio selection with various models developed from the Markowitz portfolio model. The models used in this optimal portfolio include Mean Variance (MV), Downside Deviation (DD), Mean Absolute Deviation (MAD) on the 27 BUSINESS Index on the Indonesia Stock Exchange for the period 2011-2013. From the study population of 27 shares, 10 stocks were chosen as the research sample. The results of this study explain that the MAD model is an optimal portfolio model that is able to provide high returns and optimal performance, making it right for investors with a risk seeker preference. DD is an optimal portfolio model that is able to provide the smallest risk, so this model is right for investors with a risk averse preference.

The research conducted by Mahmuda and Subekti (2017) aims to analyze portfolio performance with the Black-Litterman model using information ratio measures. The measurement of information ratio in this study uses a benchmark Capital Assets Pricing Model (CAPM) which means that investors can compare selected portfolios with benchmark portfolios. Portfolios formed from 4 shares in previous studies, namely PTBA, MYRX, LSIP, and PWON, with regard to 2 relative views, namely the prediction of LSIP stock returns will exceed PTBA and predictions of PWON stock returns will exceed MYRX. The results of this analysis show that the information ratio value is higher than the benchmark so that the Black-Litterman portfolio is concluded to have better quality performance.

Based on the theory and previous research, the hypotheses that can be formulated are as follows. H0: The Markowitz model performs better than the Black-Litterman Model

\section{Basic Theory}

\subsection{Investment Theory}

Investment is a current consumption delay to be entered into productive assets for a predetermined period of time. The delay in consumption is carried out to be invested in productive assets, so that the total utility value will increase (Hartono, 2017: 5). Investment in financial assets consists of direct and indirect investments (Yuhasril and Nianti, 2017). According to (Hartono, 2017: 7) there are two types of investment namely direct and indirect investment. Direct investment can be done by buying financial assets of a company that is traded in the capital market. Assets that can be traded on the capital market in the form of assets that have a small risk of failure, short maturities with high liquid levels such as treasury bills (negotiated) and certificates of deposit negotiated. Assets that cannot be traded are savings and deposits. Indirect investment can be done by buying securities from investment companies that have asset portfolios of other companies.

\subsection{Portfolio Theory}

Portfolio theory provides a normative approach for investors to make decisions in investing wealth in an asset or security under risk based on an assumption. that investors avoid risk and are rational. There is an assumption that investors avoid risk and are rational in nature, which means that investors tend to maximize returns by minimizing risk to diversify shares and form portfolios. This is supported by a statement by Giri and Parhi (2017), which explains that the assumption of rationality describes an investor's desire to maximize the return with the smallest risk or minimize the risk at a certain level of return when building an optimal portfolio with various asset classes.

\subsection{Return and Risk of Stock}

Return is a reward obtained from investment (Tandelilin, 2010: 102). Sources of return consist of two components, namely capital gain / loss and yield (current income). Capital gain / loss is the difference between the selling price and the purchase price of a securities, while the yield (current income) is a return component that reflects the cash flow or income obtained periodically from an investment as indicated by the amount of dividends obtained. Subashree and Bhoopal (2017) define stock risk as the difference between expected return and actual return. Risk is the difference between realized return and expected return so that the measurement of 
risk can use the concept of variance and standard deviation.

\subsection{Markowitz Model}

Markowitz's model describes investment behavior in mathematical terms based on Markowitz's groundwork in 1952 (Markowitz, 1952). Markowitz (1959) introduces a quadratic utility function that describes the attitude of investors who avoid risk. Investors who reject risk and tend to seek higher profits but don't want higher risk, this model can balance the tradeoff between risk and return. Markowitz defines standard deviation as a proxy for measuring risk.

\subsection{Black-Litterman Model}

The Black-Litterman model was first published in 1990 by Fiscer Black and Robert Litterman. Then it was redeveloped by Black and Litterman in 1992. (Black and Litterman 1991a). The Black-Litterman model provides two important contributions to the management of asset allocation. The first Black-Litterman model provides an opportunity for investors to estimate the rate of return (return) of each investment asset, namely by using a capital asset pricing model (CAPM) portfolio in a balanced state. Second, the Black-Litterman Model provides a view for investors in predicting the rate of return (return) of each asset.

\subsection{Short Selling}

Short selling is a method used by investors in the sale of shares by borrowing funds to sell shares that have not been held at high prices and have hopes of repurchasing and can return the loan shares to the broker when the stock falls. One characteristic of short sale transactions is to sell securities that are not owned by the seller. However, the seller still has an obligation to submit the securities that have been sold at a specified time. This is done with the aim of fulfilling these obligations, the settlement of which is among others by borrowing securities.

\section{Methodology}

The population of this study is companies on the LQ-45 Index during the observation period February 2015 to January 2018. The companies selected in this study are listed companies during the observation period February 2015 to January 2018 respectively. The method of determining the sample using a purposive sampling method with the criteria of companies listed during the observation period February 2015 to January 2018 respectively. The number of observations that became the study sample were 36 observations with the observation period February 2015 to January 2018 being 108 observations. Furthermore, an individual stock return calculation will be carried out until the optimal portfolio calculation. Then to calculate portfolio performance is calculated by the Sharpe index. Then calculate the portfolio performance calculated by the sharpe index on each model:

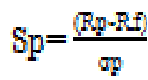

Information:

Sp : Sharpe index

$\mathrm{Rp} \quad$ : Portfolio return during the observation period

Rf : Risk free returns during the observation period

$\sigma_{\mathrm{p}} \quad$ : Total portfolio risk from systematic risk and unsystematic risk

The non parametric test used in this study is the Willcoxon test. According to Wahid Sulaiman (2002: 79), the Willcoxon test is used to fill the significance of the comparative hypothesis 2 (two) independent samples of the same size and the data in the form of ordinal. This test is most often used by researchers when they want to avoid assumptions from t-test statistics (eg sample data follows a normal distribution). The stages of analysis are as follows.

1) Formulation of the hypothesis

H0: There is a significant difference between the first sample average and the second sample average.

H1: There is no significant difference between the first sample average and the second sample average.

2) Basic decision making

Decision making is based on a comparison between the value of Asymp. Sig. with a level of significance (alpha $=0,05)$ used in this study. The comparison is as follows.

If: Asymp. Sig. (2-tailed) $<0,05$ so $\mathrm{H} 0$ is accepted

If: Asymp. Sig. (2-tailed) $\geq 0,05$ then $\mathrm{H} 0$ is rejected. 


\section{Results and Discussion}

\subsection{Optimal Portfolio Performance}

Table 1 Optimal Portfolio Performance

\begin{tabular}{ccc}
\hline Portfolio & $\begin{array}{c}\text { Sharpe index } \\
\text { Markowitz model } \\
{\left[\mathrm{Sp}_{\mathrm{M}}\right]}\end{array}$ & $\begin{array}{c}\text { Sharpe index } \\
\text { Black-Litterman model } \\
{\left[\mathrm{Sp}_{\mathrm{B}}\right]}\end{array}$ \\
\hline $\mathrm{A}$ & $-0,037545$ & $-0,332247$ \\
$\mathrm{~B}$ & $-0,097533$ & $-0,382113$ \\
$\mathrm{C}$ & $-0,104520$ & $-0,358152$ \\
$\mathrm{D}$ & $-0,064681$ & $-0,242281$ \\
E & 0,366602 & $-0,129388$ \\
F & $-0,084322$ & $-0,273208$ \\
G & $-0,060080$ & $-0,112436$ \\
H & 0,549396 & $-0,235307$ \\
I & 0,406765 & $-0,075724$ \\
J & $-0,133011$ & $-0,241341$ \\
\hline
\end{tabular}

Source: SPSS though, 2019

Table 1 explains that the Markowitz Model has a Sharpe index greater than the Black-Litterman Model. This can be interpreted that the Markowitz Model can provide the best analysis to determine an efficient portfolio.

\subsection{Statistical test results}

The results of the Wilcoxon Signed Ranks Test statistical test in this study are presented in Table 3 as follows.

Table 2 Kinerja Portofolio Optimal

Source: SPSS though, 2019

\begin{tabular}{lr}
\hline & SpB - SpM \\
\hline $\mathrm{Z}$ & $-2,803^{\mathrm{b}}$ \\
Asymp. Sig. (2-tailed) & 0,005 \\
\hline
\end{tabular}

The results of the statistical hypothesis testing of the study using the SPSS analysis program Wilcoxon Signed Rank Test statistical test showed an $\mathrm{Z}$ value of -2.803 at a significance level of 0.005 . Therefore, 0.005 0.05 , it can be said that there is a significant difference between the sharpe index of the Markowitz Model and the Black-Litterman Model, so the hypothesis is accepted.

\subsection{Discussion of Results}

Comparison of portfolio performance between the Markowitz Model and the Black-Litterman Model can be seen from the Wilcoxon Signed Rank Test statistic which shows a Z value of -2.803 at a significance level of 0.005 smaller than 0.05, which means there are significant differences between the Markowitz Model and the BlackModel Litterman. Descriptive statistics explain that the highest maximum value is indicated by the Markowitz Model sharpe index of 0.54939 . This means that the best portfolio performance is owned by the Markowitz Model, so the hypothesis is accepted.

The use of the Markowitz Model is in accordance with the portfolio theory that selects stocks by combining these stocks to reduce risk. This is because if at any time one of the shares included in the portfolio decreases or the company is in an unstable condition, then the shares of other companies can minimize losses due to the investment of shares chosen by the investor. The implementation of this theory is by the way investors divide funds into several types of investments to reduce the risks borne (Djamaluddin et al., 2017).

The results of this study are in line with research by Cevizci (2016) which examined the comparison of optimal portfolio performance in three optimization methods. This research shows that Markowitz's model, which is not limited by short selling, produces the highest utility, causing the weight of the portfolio to be high value on short selling. On the other hand, the Black-Litterman Model prohibits short selling. This makes the portfolio weight in the Black-Litterman Model worth less than the Markowitz Model. Other similar research results are Martin and Lukas (2015) and Wirawan (2017) who also provide consistent empirical evidence, namely the best portfolio performance between the Markowitz Model and the Black-Litterman Model shown by the Markowitz Model.

\section{Conclusion}

Based on the results of data analysis, this study found that the Markowitz Model indicated short selling was different from the Black-Litterman Model which did not short sell. This causes the Sharpe index on the Markowitz Model to be higher than the Black-Litterman Model. This research also proves that the Markowitz 
Model is proven to be able to reduce the highest risk, resulting in a sharpe index higher than the Black-Litterman Model. Investors and investment managers can consider the Markowitz Model as a basis for portfolio investment. However, in this case managers are advised not only to rely on historical data that is sometimes difficult to obtain, but can use the analysis of the current conditions to diversify portfolios using the Markowitz model. In addition, the results of this study can also be a consideration for investors to combine the use of models as an analysis of portfolio investment. Because, changes in world conditions are fast, it is very necessary to adjust for the expected changes when investors play an important role in portfolio optimization.

\section{References}

Djamaluddin, S., Kurnia, N., and Djumarno. 2017. Analysis of Return to Beta in Forming the Optimal Portfolio of Stocks on LQ-45 in Indonesia Stock Exchange. International Journal of Business Marketing and Management (IJBMM), 2 (9), pp: 1-15.

Hangonowati, DA and Faisal, Fithra. 2017. Awaiting Certainty: Indonesian Economy After Trump's Election. Faculty of Economics and Business, University of Indonesia. Quarterly Report, 1.

Giri, Kanta Laxmi and Parhi, Gayadhar. 2017. Optimum Portfolio Construction Using Single Index Model. Intercontinental Journal of Finance Research Review, 5 (2), pp: 62-69.

Hartono, Jogiyanto. 2017. Portfolio Theory and Investment Analysis. Eleventh Edition. BPFE. Yogyakarta.

Kshatriya, Saranya and Prasanna, Krishna. 2014. Portfolio Selection and Optimization with Higher Moments: Evidence from the Indian Stock Market. Asia Pasific finan Markets, 21 (2), pp: 133-149.

Mahmuda, Hanif Syarif and Subekti, Retno. 2017. Black-Litterman Performance Assessment Analysis Using Information Ratio with Benchmark Capital Assets Pricing Model. Mathematical Journal, 6 (4), h: 52-58.

Markowitz, Harry. 1952. Portfolio Selection. The Journal of Finance, 7 (1), pp: 77-91.

Martin, Sirucek and Lukas, Kren. 2015. Application of Markowitz Portfolio Theory by Building Optimal Portfolio on the US Stock Market. Acta Universitatis Agriculturae et Silviculturae Mendelianae Brunensis, 63 (4): 1375-1386.

Mary, J. Francis and G. Rathika. 2015. The Single Index Model and The Construction of Optimal Portfolio with CNXPHARMA Scrip, International Journal of Management, 6 (1), pp: 87-96.

Ministry of Finance of the Republic of Indonesia. 2017. Survey Results of UNCTAD, Indonesia Jump to Ranking 4. Available on URL: https://www.kemenkeu.go.id/publikasi/berita/hasil-survei-unctad-indonesialompat-ke-ranking-4/. Accessed on November $23^{\text {rd }}, 2018$.

Ramadhan, Handayani, Maria Goretti Wi Enandg. 2014. Analysis of Optimal Portfolio Selection with Models and Development from Markowitz Portfolio (Study on BISNIS-27 Index on the Indonesia Stock Exchange 2011 - 2013 period). Business Administration Journal (JAB), 14 (1), pp : 1-10.

Wirawan, Thedy. 2017. "Stock Portfolio Performance Based on the Momentum Strategy with the BlackLitterman Model on the Indonesia Stock Exchange" (Thesis). Denpasar: Udayana University.

Yuhasril and Nianti, Eva. 2017. Using The Single Index Model to Decide to Invest in Share Jakarta Islamic Index Period of 2012-2015. European Journal of Business and Management, 9 (24), pp: 96-109. 